\title{
A Reflective Essay on What Public Relations Is: Its Role in Strategic Communication Management in Organizations and MNCs
}

\author{
Kwesi Atta Sakyi ${ }^{1}$, Geoffrey Mweshi ${ }^{2}$, David Musona ${ }^{3}$, Esnart Mwaba Tayali ${ }^{4}$ \\ ${ }^{1}$ Directorate of Research Consultancy and Innovation, ZCAS University, Lusaka, Zambia \\ ${ }^{2}$ Social Science Department, ZCAS University, Lusaka, Zambia \\ ${ }^{3}$ Accounting and Finance Department, ZCAS University, Lusaka, Zambia \\ ${ }^{4}$ Department of Work Employment and Organization, University of Strathclyde, Glasgow, Scotland
}

Email address:

kwesiattasakyi449@gmail.com (K. A. Sakyi),kwesi.sakyi@zcas.edu.zm (K. A. Sakyi), Geoffrey.Mweshi@zcas.edu.zm (G. Mweshi), david.musona@zcas.edu.zm (D.Musona),estayali@gmail.com (E. M. Tayali)

\section{To cite this article:}

Kwesi Atta Sakyi, Geoffrey Mweshi, David Musona, Esnart Mwaba Tayali. A Reflective Essay on What Public Relations Is: Its Role in Strategic Communication Management in Organizations and MNCs. Science Journal of Business and Management.

Vol. 8, No. 3, 2020, pp. 106-111. doi: 10.11648/j.sjbm.20200803.11

Received: April 27, 2020; Accepted: June 2, 2020; Published: June 23, 2020

\begin{abstract}
This article has the objective of clarifying what public relations is all about in connection with how large corporate entities or MNCs manage or handle strategic communications. In the past, we have seen the demise of large Multinational Corporations due to scandals and failure to handle crisis such as oil spills, handling clients' money during global financial crunch such as the sub-prime mortgage financial crisis of 2007-2009. That crisis saw the demise of huge corporations such as Lehman Brothers, Anderson \& Anderson, Freddie Mae, and Freddie May, among others. Failure to handle various publics and interest groups strategically can spell the doom of a company or a nation. This article took an exploratory approach since the authors wrote the article for a master's course and not as professionals in public relations. The methodology adopted was that of desk research based on secondary data sources accessed from books, the internet and journal articles. The author also did a lot of observations and reflection to come up with the insights expressed in this paper. The paper was also approached from a multidisciplinary point of view to give it breadth. The findings and conclusions are that in modern times, corporations and nations should utilize the speed, flexibility, transparency, interactivity, global reach, and easy accessibility of Social Media to engage various publics in a crisis in order to gain credibility and show their human and humane qualities of empathy, humility and readiness for fruitful discourse and dialogue. However, CEOs and political leaders such as Presidents of countries are judged by the way they conduct themselves on Social Media such as Facebook or Twitter, and their chances of re-election hinge on their tweets and mis-tweets. On Social Media, users are always called upon to observe netiquette or urbane and civilized behavior.
\end{abstract}

Keywords: Bloggers, COVID-19, Crisis Management, Publics, Public Influencers, Public Relations, Public Opinion, Social Media, Strategic Communications, Opinion Leaders

\section{Introduction}

When we learnt that the next Course we were going to take on our MBA programme was Strategic Communication Management, we became perplexed and anxious with curiosity how this Course would be different from the previous courses that we had completed and also the general knowledge we had had. This curiosity made us search a lot in order to know the contents of the course, and after sifting through a host of course outlines online, we settled for the course outline from the University of Texas which is given at the end of this article as Appendix A.

The course we took opened our eyes to the fact that Public Relations is neither Business Communication nor Marketing nor a mixture of the two but a different course which addresses the needs of modern corporate entities and nations, especially the giant Multinationals that straddle across many geographical borders. 
MNCs are not islands as their business activities interface with political, social, technological, environmental, ethical, legal, and economic issues. In that regard, they need a department that deals with corporate affairs and that acts as a boundary spanner or linking-pin so that the organisation stays in sync or in touch with reality. In the same manner, political leaders have found it expedient these days to use social media to reach the public.

Swift and expeditious communication is to help the company or political administration avoid strategic drift and sequestration from its valued constituents and stakeholders. Therefore the Corporate Affairs Division or Public Relations Department has the onerous duty of choreographing the image and reputation of the MNC by acting as its spokesperson, interpreter, megaphone, disseminator, diplomat, trouble-shooter, information exchange, corporate face, spin doctor, and boundary spanner [13, 15, 17] The MNC's PR person should be someone savvy, au-fait and experienced in damage limitation control, as well as in calming frayed nerves. He or she should be of high integrity, honest, loyal and well-read, preferably a mid-career public media professional with decades of experience in the media or marketing $[10,11,18]$ The same goes for the spokesperson of the government or President.

Corporate organisations often find themselves in media scandals as well as in Social Media mud-slinging because of their huge operations and their enormous reach. This article addresses the areas of Public Relations (PR) that we have been exposed to in our studies as post-graduate students by using some conceptual frameworks in tables and charts. The article explores the areas of PR that we have understood from the many Discussions on the AstriaLearning portal with our course mates and also from engagement in assignments such as writing this article. This article discusses public relations (PR) side by side with strategic communications (SC).

\section{Theoretical Background}

The Course Strategic Communications Management has empowered us with more IT skills as now we can use some skills to draw tables and charts as seen enclosed herewith. Also we have come to respect Social Media a lot as we used to view it with negativity. We used to think that it was for the young ones and those who are less busy with work. Now it is obvious that the social media platform, Twitter, has become the formal and preferred channel of communication by some world leaders such as Donald Trump of the USA, former President John Mahama of Ghana, former President David Cameron of the UK, and President Nana Akufo-Addo of Ghana, among many others.

[31] stated that in September 2013 when the then Prime Minister (PM) of UK, David Cameron had tweeted that five British nationals had been lost in the Westgate Mall terrorist attack in Nairobi, Kenya, the tweet went viral and it showed the power, speed, potency, efficacy, reach and costeffectiveness of social media because the British tabloids, the
Mirror and the Independent newspapers, took five days to confirm and report what the PM had earlier on tweeted.

[1] define strategic communications as communication which aligns with the overall corporate strategy of a firm to enable it to attain its long term objectives. [1] in their article decried the short-term view to communication taken by some companies to their detriment by not considering the long term implications of their actions and inactions communicated in their communiqués and behaviours during times of crisis such as Exxon's Valdez Mobil oil spill along the Alaskan coast in 1989, BP Oil spill along the Gulf Coast in April 2010, and Enron's scandal in 2002 which led to the enactment of Sarbanes-Oxley Act 2002.

Some companies sell inappropriate products such as MacDonald's beef-flavoured chips sold in India, Merck's reaction to a dangerous drug on the market, Glencoe Mopani Copper Mine's recent decision in Zambia (April, 2020) to lay off 40,000 workers without consultations with stakeholders, among other numerous examples, all speak to the fact that these instances show lack of strategic communications in place in these cited examples.

[31] alluded to the fact that David Cameron had been a sceptic of social media as he once remarked that 'too many tweets made a twat'. It is obvious that Cameron must have eaten back his words, for the stone that was rejected became the cornerstone, as the holy tome puts it. In the Nairobi Westgate Mall attack that occurred on $21^{\text {st }}$ September 2013, sixty seven people (67) were killed and a hundred and seventy five (175) were injured.

According to [31] audiences are passive spectators and listeners while publics are specially identified interest groups with common characteristics to whom some message or communication can be targeted effectively as we can engage them in a two-way symmetrical communication via social media in an interactive manner. Wilson also observed that the expression general public does not exist in marketing parlance because it is nebulous, amorphous and nondescript.

Wilson stated that the term general public cannot be measured nor be properly demarcated or delineated and as such we should desist from using it. Instead we should refer to various publics or interest groups who we can engage meaningfully, strategically and realistically. [31] stated that public influencers are opinion leaders and bloggers who have clout and who can be targeted so that they can in turn get through to their hooked admirers and followers on social media.

According to [25], strategic communications emerged in the 1980s in the USA when one Professor Schulz and his colleagues at North Western University (USA) came to the conclusion that the $21^{\text {st }}$ century required a new form of creative and competence-based communication that is effective and unbiased.

Many people had seen the advertising lies and unethical stances taken by commercial advertisers to deceive the gullible public with advertising pranks, gimmicks and deceitful messages. Thus strategic communications was to take a more ethical and truthful stance by engaging various publics in multi-dimensional media such as the use of social media 
platforms. These platforms include Twitter, Instagram, Facebook, YouTube, LinkedIn, and Twoo, among many others.

We have now understood the power, speed, and global reach of Social media which sits on many platforms such as laptops, smart phones, desktops, and tablets. We know now that we need to address specific publics with direct persuasive messages in times of crisis such as Corona Virus 2019 pandemic (COVID-19) or during national outrage such as happened in the USA after George Floyd was murdered in cold blood on 25 May 2020.

Political leaders as well as civic leaders have to show their leadership during such trying and dire moments in time. Apart from using the traditional methods of TV channel daily briefings, they also have to take to less formal means of communication such as Twitter, Facebook, Instagram, Zoom, Youtube, and LinkedIn, among others to engage their various publics and to drill down their message to the grassroots level.

We also know something about damage control limitation where a crisis has to be handled in the international media such as when Exxon Mobil and BP had large oil spills. We have learnt that during such crises, there is need for leaders to show honesty, correct timing, and specifically-targeted and carefully-choreographed messages which are targeted at various specific publics instead of targeting mass and nebulous messages at undefined audiences. In the USA, George Floyd, an African-American was brutally murdered by police officers in Minneapolis, Minnesota State on Monday 25 May 2020 [2] The political leadership did not handle the crisis in a politically-correct and diplomatic manner as they resorted to the use of threats and inflammatory language that worsened the situation, leading to riots, looting and protests all over America in an unprecedented manner. In such crisis, words have to be chosen carefully and Social Media is not the correct place to address critical national issues. Such emotionally-charged moments call for calm, and the use of right timing and right media to address the various publics with various wellcrafted speeches that express sentiments and feelings of the people and that resonate with the various publics with different claims but all of them with the ultimate passion of the greatest good for the greatest number. Also during crisis, leaders should coordinate their messages to avoid misinformation, information-overload, padding, and confusion as is the case right now with what is happening with the briefings on COVID-19 $[16,20]$ Not only should political leaders show leadership but also they should allow experts to talk on technical issues. Many observers have concluded that leadership mettle can be judged better in times of crisis and during emergencies in the way leaders handle issues and themselves during press briefings $[6,17$, 22]

Audiences are nondescript and heterogeneous or passive recipients of messages while publics are actively-engaged people or segments of audiences with particular interests and who are affected directly or indirectly by an incident during an emergency such as COVID-19 [27, 29]

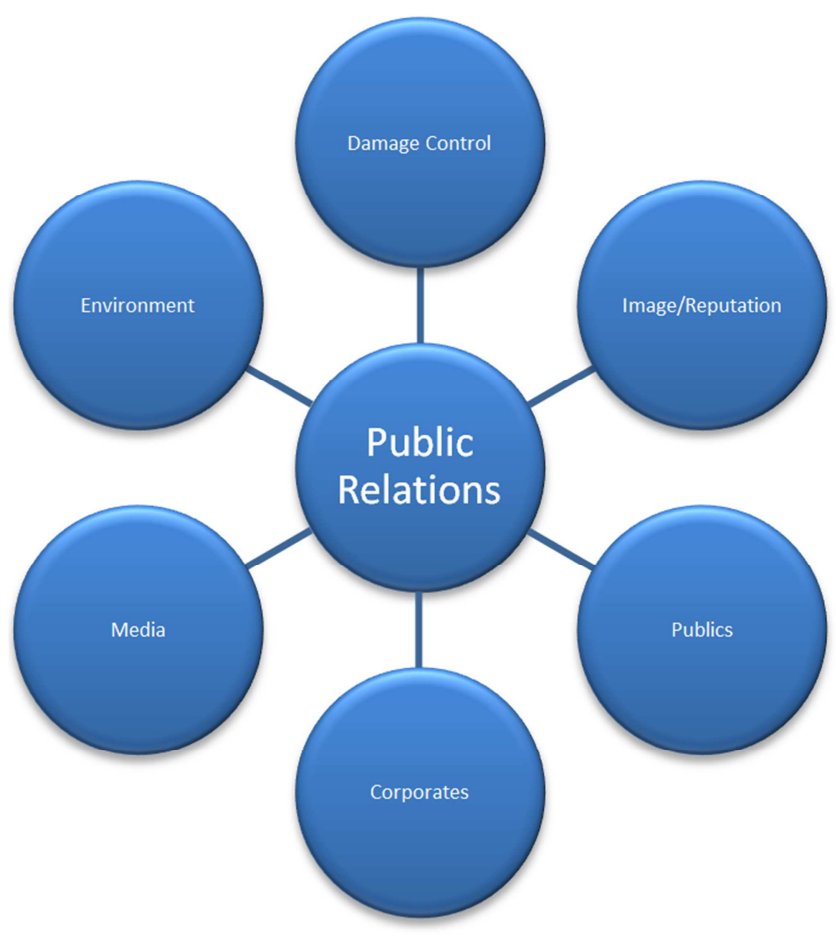

Figure 1. Broad areas of Public Relations.

Figure 1 above identifies the broad areas of concern for public relations practitioners as their activities of information management and communication aim at the core areas of the micro- and macro-environments, the media, the maintenance of high corporate image to win goodwill, various publics with their diverse needs and concerns, and corporate needs, among others [31] Strategic Communications is defined by the experts as the purposeful application of communication by an organisation to achieve its goals and mission through the processes of using influence, persuasion, agenda-setting, being a good corporate citizen through overt and covert activities such as engaging in Corporate Social Responsibility activities, among others [6, 10, 11, 21, 22] Public Relations officers of the MNC work hard as boundary spanners to integrate the internal environment of the organisation with the external environment, and in the process, they act as corporate filters, gatekeepers, and ears and eyes of the organisation in their day-to day intercourse and engagements with internal and external customers [15, 17, 20]

Public relations and strategic communications blend aspects of engaging in marketing campaigns, fence-mending, networking, propaganda, testing the waters or flying the kite, and building bridges for the organisation. Sometimes, knowingly or unknowingly, PR practitioners may engage in massaging the message to be delivered to some identified publics. The success of this depends upon their charm, experience, and the gullibility of their target group.

PRs have to decide when messages should be released by the press by placing embargo release dates on them, and part of their strategy would include deciding the correct timing for releasing the communication, how much of it to release, should it be piecemeal or the whole message, where and 
which channel or media to use, what choice wording to use, what ambience to create when releasing the message, what feedback to expect, what reinforcement to give to the message, how to measure the feedback response, readiness to receive and accept the response, among other strategic considerations $[19,28]$ Communication is a two-way street as it has action and reaction [7] Communication can be couched in a way so as to judge public opinion on an issue. Therefore, communication can be targeted at influential opinion leaders or bloggers or community leaders who in turn can influence their followers to have a boom or multiplier effect. In this way, communication becomes effective if it is segmented for the audience by using targeted messaging such as short- messaging- service (sms) transmitted through an internet service provider (ISP).

According to [5] Strategic Communications falls under Public Relations and it comprises areas such as Marketing Communications, Health Communications, Political Communication, Issues Communication, Risk Management Communication, Industrial Relations Communication, Crisis Communication, Environmental and Science Communication, Public Diplomacy Communication, Public Safety Communication, Disaster Management Communication, Counter-Terrorism Communication, and Token Communication, among many others [23, 24, 26, 27]

\section{Application of Acquired Knowledge in Future Endeavours}

Being lecturers, the knowledge that we have acquired on this course will come in handy in lecturing and also in consultancy work as well as in developing and publishing academic articles. Furthermore, personally it will be beneficial to us in our personal lives in knowing the importance of Social Media and applying it judiciously in our lives. We hope to guide our families as well as our students on the importance of Social Media in networking and in getting messages quickly out there in the world. It will help in online sales, fundraising and networking with partners for support for business ventures such as our desire to publish books and novels to sell.

\section{Knowledge That I Am Curious About}

We were fascinated by how giant MNCs handle major crises affecting their reputation and image, and the amount of compensation they have to pay as well as the Corporate Social Responsibility they do to redeem their image. This is an area for further research [10, 11, 13, 22, 24, 27]

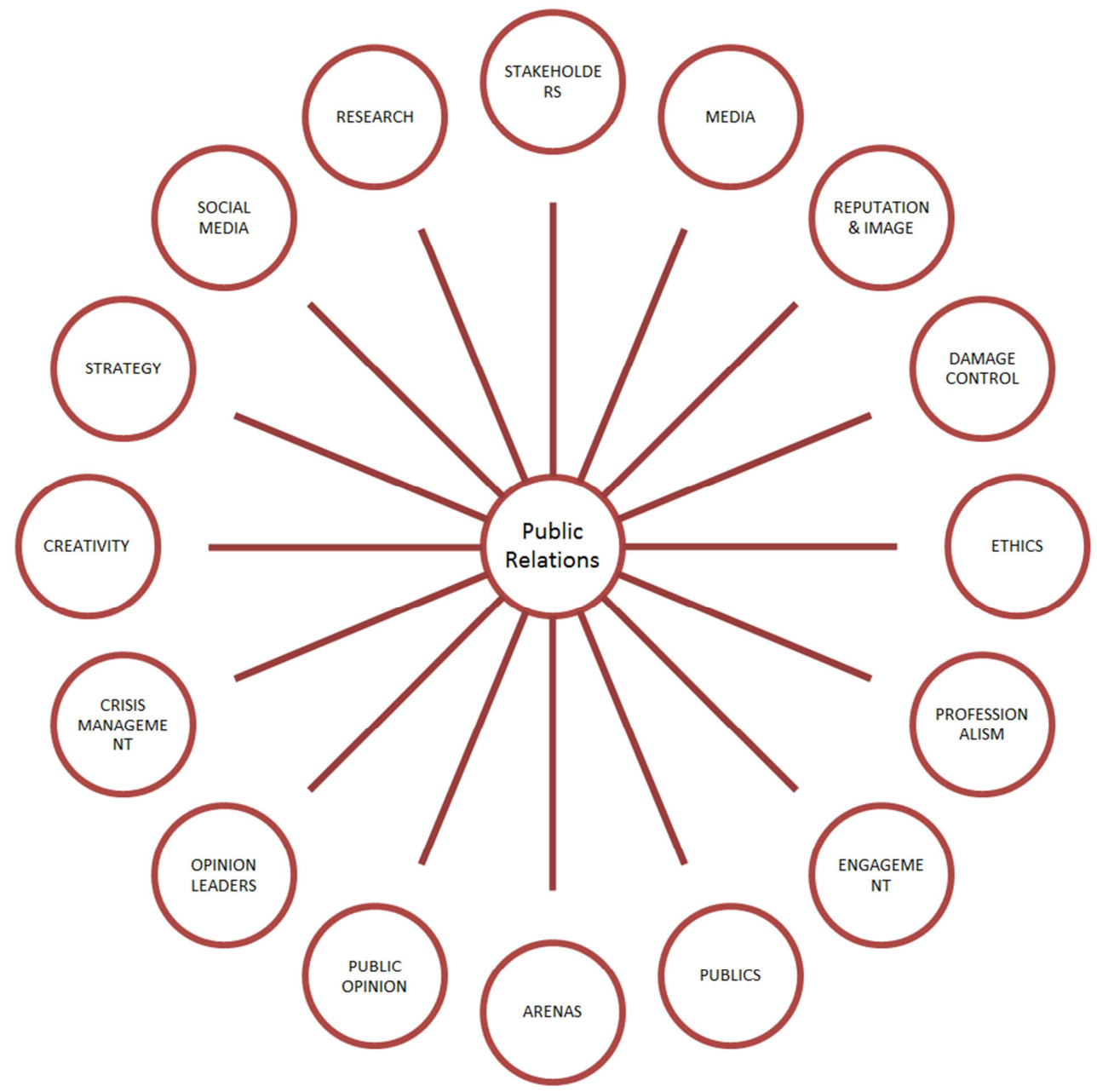

Figure 2. Conceptualization of Public Relations Issues. 
This section speaks to Figure 2 above about the nitty-gritty of Public Relations and practitioners who come in different forms. Some have academic backgrounds and others come from industry such as from the electronic and print media. Some are professionals while others are stop-gap PRs. PR officers are expected to observe professional ethics in their daily routines. They are expected to be faithful and loyal to their employers and at the same time not to desert the professional standards set for them by their professional regulatory bodies. This brings about a conflict of interest which must be handled professionally $[6,9,18]$

Each practitioner is expected to have their own personal value clarification to guide them in their decision making, whether to adopt the cosmopolitan view of loyalty to their professional body or to adopt the parochial view of serving the interest of their employers. In developing countries such as Ghana and Zambia, the levels of poverty make PRs vulnerable to malfeasance because of the poor conditions of service in most public and private organisations.

\section{Further Knowledge to Explore}

In future, we will like to learn more about the roles of Corporate Affairs Managers, Liaison Officers or Boundary Spanners, and Link Pins as well as those of Business Development Managers.

\section{Conclusion}

Strategic Communication Management is a new area which is work- in- progress and an area gaining much ground because of increased activities of MNCs. It is a field worth studying as it opens up one by exposing one to a wide field of knowledge. Appendix A below shows the Table of Contents for Texas University Third Year SCM Course. We conclude by stating that MNCs and politicians should act with caution when handling crises because they will be dealing with various publics and it will be germane to segment the publics and address them using the right media platform. Those politicians who choose to use social media should observe netiquette and use urbane and civilized words to avoid hurting people's feelings.

\section{Appendix}

(SC Course Outline)

University of Texas

BGS373 Strategic Corporate Communication

Lead Person: Jeffery Paterson

1. Ethics and Public Relations

2. Government Relations and Lobbying

3. Corporate Political Activity

4. Public Issues Management

5. Investor and Shareholder Management and Relations

6. Employee Relations
7. Social Media/Media Relations

8. Stakeholder Relations

9. Digital Media Networking

10. Corporate Community Relations

11. Corporate Social Responsibility

12. Crisis Management Relations

13. Corporate Image, Reputation, and Branding Relations

14.Public Opinion

15. Audience and Publics

16. Tactics and Campaigns

17. Theories of Strategic Communication

18. History of Strategic Communication

19. Globalisation and Informatics

20. Integrated Communication

21. Media Advocacy, Engagement, Influence, and Persuasion

22. Damage Limitation Control

23. Research

\section{References}

[1] Argenti, P. A., Howell, R. A. \& Beck, K. A. (2002) The Strategic Communication Imperative MIT Sloan Review.

[2] BBC (2020) George Floyd: What happened in the final moments of his life [Online] Retrieved from https://www.bbc.com/news/world-us-canada-52861726

[3] Berger, B. K. (2008) Employee Organization Communication Institute of Public Relations 2008 http://www.instituteforpr.org/employee-organizationcommunication/

[4] Blanchard, O. (2014) Social Media ROI: Managing and Measuring Social Media Efforts in your Organization London: Que Publishing.

[5] Bocan, C. H. (2017) Strategic Communication and Practice: The Cocreation Model New York, N. Y.: Wiley Publishing Inc.

[6] Boothby, F. Social Media Best Practice Guide http://usefulsocialmedia.com/assets/pdf/USMBriefing.pdf

[7] Bovee, C. L., Thill, J. V. \& Schatzman, B. E. (2003) Business Communication Today Singapore: Pearson Education.

[8] Brown, D. L., Vetterlein, A. \& Roemer-Mahler, A. (2010 Theorizing Transnational Corporations and Social Actors: An Analysis of Corporate Motivations Business and Politics Vol. 2 No. 1, 2015, 9 July.

[9] Carroll, A. B. \& Bucholtz, A. K. (2003) Business and Society Ethics and Stakeholder Management $\left(5^{\text {th }}\right.$ ed.) Australia: Thomson South Western.

[10] Coombs, W. F. (2007) Crisis Management and Communications Institute for Public Relations 2007 www.instituteforpr.org/topics/crisis-management-andcommunications/

[11] Coombs, W. T. (n.d.) Protecting Organizational Reputation during a Crisis: The Development and Application of Situational Crisis Communication Theory Corporate Reputation Review Vol. 10 No. 3 pp. 163-176. 
[12] Corporate Social Responsibility (2014) Encyclopedia for Business ( $2^{\text {nd }} \quad$ ed.) $\mathrm{http}: / / \mathrm{www}$. referenceforbusiness.com/management/comp$\mathrm{de} / \mathrm{aCSR} / \mathrm{actual}$

[13] Cornelissen, J. (2008) Corporate Communication Guide to Theory and Practice Los Angeles, C. A.: Sage Publishers.

[14] Crisis Communication Plan: A Public Relations Blueprint https://www3.niu.edu/newsplace/crisis.html

[15] Dougal, E. (2008) Issues Management Institute of Public Relations December, 2008 pp. 153-219.

[16] Goodman, M. \& Hirsch, P. (2010) Strategic Adaptation for Global Practice in Corporate Communication: Strategic Adaptation for Global Practices New York, N.Y.: Peter Lang pp. 141-153.

[17] Laskin, A. V. (2011) How Investor Relations Contribute to the Corporate Bottom-line Journal of Public Relations Research Vol. 23 pp. 302-324.

[18] Lux, S. T., Crook, R. \& Woehr, D. J. (2011) Mixing Business with Politics: A Meta-Analysis of the Antecedents and Outcomes of Corporate Political Activity Journal of Management Vol. 37, No. 1 January 2011 pp. 223-247.

[19] Mullins, L. J. \& Christy, G. (2010) Management and Organisational Behaviour Harlow, England: Pearson Education.

[20] Patterson, J. (2015) Multinationals have become social and political actors who need to address publics in a constant flow of information.

[21] Prweb.com (n.d.) How to write a successful News Release PRWeb http://service.prweb.com/learning/article/how-towrite-a-successful-news-release
[22] Shum, P. K. \& Yam, S. L. (2011) Ethics and Law: Guiding the Invisible Hand to Correct Corporate Social Responsibility Externalities Journal of Business Ethics 2011, Vol. 98 pp. 549571.

[23] Smith, R. (2012) Analyzing the Organization's Strategic Planning for Public Relations New York, N. Y.: Routledge Press.

[24] Smudde, P. M. \& Courtright, J. (2011) A Holistic Approach to Stakeholder Management: A Rhetorical Foundation Public Relations Review Vol. 37 No. 2 pp. 137-144.

[25] Starykh, N. (2018) Communication theories and design practices of strategic communications in social field [Online] DOI. 10.30547/worldofmedia.2.2018.2.

[26] Straubhaar, J. \& LaRose, R. (2010) Media Now: Communication Media in the Information Age ( $3^{\text {rd }}$ ed.) Connecticut, USA: Wadsworth Publishing pp. 324-368.

[27] Watson, D. (2015) 5 of BPs Biggest Gulf Oil Spill PR Blunders Regan's PR Daily 9 July, 2015.

[28] Wilcox, C. \& Shin, R. (2011) Public Relations [Online] Retrieved from: Dennis-Wilcox/dp/020578169.

[29] Wilson, L. J. \& Ogden, J. D. (2008) Strategic Communication Planning for Effective Public Relations and Marketing (5 ed.) Kendall-Hunt Publishing (p. 284).

[30] WikiHow.com (n.d.). How to write a Press Release WikiHow http://www.wikihow.com/write-a -press-release

[31] Wilson, L. J. (2017) Strategic Communications Planning for Public Relations and Marketing. 